\title{
Effect of Humic Acid Application on Quantitative Parameters of Sugar Beet (Beta vulgaris L.) Cv. Shirin
}

\author{
Amir Rahimi $^{1}{ }^{*}$, Mustafa Kiralan ${ }^{2}$, Fatemeh Ahmadi ${ }^{3}$
}

\begin{abstract}
The present experiment aimed to investigate the influence of humic acid application on qualitative traits of sugar beet cv. 'Shirin' basis of a randomized complete block design with four replications during 2007-2008. The plants were treated with different humic acid treatments (control, 200, 300, 400, 500, and $600 \mathrm{~kg} \mathrm{ha}^{-1}$ ). The nonsugar components such as potassium, sodium, aminonitrogen and some qualitative parameters for sugar processing such as alkalinity, root yield, sugar percent, recoverable sugar, and sugar content in molasses were determined according to standard methods. According to results, humic acid application enhanced sugar quality of sugar beet. The lowest value of $\mathrm{K}, \mathrm{Na}$ and amino-nitrogen were observed in $\mathbf{H 3 0 0}$ sample $\left(300 \mathrm{~kg} \mathrm{ha}^{-1}\right)$ with 3.85 meq $100 \mathrm{~g}^{-1}$ pulp, $1.22 \mathrm{meq} 100 \mathrm{~g}^{-1}$ pulp and $1.21 \mathrm{meq} 100 \mathrm{~g}^{-1}$ pulp, respectively. The highest recoverable sugar content $(15.64 \%)$ was obtained from $300,400,500$, and $600 \mathrm{~kg} \mathrm{ha}^{-1}$ application. Also, the highest sugar yield resulted from 400,500 , and $600 \mathrm{~kg} \mathrm{ha}^{-1}$ and the lowest sugar content in molasses were observed in the treatments of 200 and 300 $\mathrm{kg} \mathrm{ha}^{-1}$ humic acid.
\end{abstract}

Keywords: Alkalinity, Molasses, Sugar content, Sustainable agriculture

\section{INTRODUCTION}

Sugar beet (Beta vulgaris L.) is a diploid and biennial crop which is the main source of sucrose and has a considerable role in gross domestic production (GDP) of Iran (Asadi, 2007; Rahimi et al., 2019). The Shirin cv. of sugar beet is a common species that is monogamous and diploid in terms of bud type (Akhtar et al., 2017). There are numerous reports about the sugar beet as a vital crop to man as a source of high energy and an important source of feed to livestock (Dawood et al., 2019). The importance of this crop comes from its growing in the newly reclaimed land and giving a high sugar recovery, as well as its lower water requirement. Moreover, sugar beet is specialized as a short duration crop, where its growth period is about half that of sugarcane (El-Sayed et al., 2019). Also, sugar beet being often, the most important cash crop in the rotation, it leaves the soil in good conditions for the following summer cereal crop (Nemeata et al., 2018).
So that, it became the first source for the production of sugar in Iran, as repeated. The production of sugar from sugar beet reached $61.32 \%$ (2.11 Million tons) of sugar production in Iran.

Nowadays Iran faces many problems that affect the productivity of crops in general and sugar crops in particular, including sugar beet, which evolves, significantly, at the moment. For example water and soil fertility crisis. Therefore, that humic acid (HA) is a main component of humic substances, which are the major soil organic constituents (humus). Humic substances are commercially products which consist of some organic molecules that originate from decomposition, microbial activity of dead biological material and plant tissues (Orsi 2014; Ekin, 2019). It is produced by biodegradation of organic matter. Humic acid is not a single acid; rather, it is a complex mixture of various acids containing carboxyl and phenolate groups. Humic acids contain form complexes and ions that are commonly found in the environment creating humic colloids (El-Hassanin et al., 2016; Kaya et al, 2018). Fulvic acids are humic acids of lower molecular weight and higher oxygen content than other humic acids however, they are commonly used as a soil supplement in agriculture (Kheir and Kamara, 2019). Besides, these substances decrease the negative effects of chemical fertilizers (Osman and Rady, 2012; Aly et al., 2017). There are different literatures about humic acids in agriculture applications. Gomaa et al. (2014) reported that application humic acid increased significantly grain yield of maize. Also, Fuentes at el (2018) showed that application of humic acid caused a significant increase of sucrose, root yield and refined sugar yield and a reduction in molasses forming substances content, compared to the control. However, EL-Hassanin at el (2016) reported that foliar application of humic acid statistically improved sucrose, extractable sugar, purity, sugar lost to molasses, extractability percentages and yield of sugar beet. Pospíśilová et al (2018) declared that humic acid application on corn plants improve shoot and root growth. Especially, yield in dry matter of corn shoots was increased with humic

DOI: $10.21608 / A S E J A I Q J S A E .2020 .79757$

${ }^{1}$ Faculty of Agriculture, Department of Agronomy,

Urmia University, Urmia, Iran (Corresponding author: emir10357@gmail.com;

e.rahimi@urmia.ac.ir, P.O. Box 57561-51818)

${ }^{2}$ Faculty of Engineering and Architecture, Department of Food Engineering,

Abant Izzet Baysal University, Bolu, Turkey

${ }^{3}$ Faculty of Agriculture, Department of Soil Science,

Urmia University, Urmia, Iran

Received December 30,2019, Accepted March18, 2020 
acid application. In forage turnip, using humic acid increased roots and leaf dry matter (Albayrak and Camas 2005).

Although there are a lot of reports on sugar beet quantitative properties, there is a very little studies about quantitative properties of sugar beet cv. Shirin in Iran as affected by foliar application of humic acid, so this study deals with the effect of humic acid foliar application at different concentrations on some quantitative properties of sugar beet cv. Shirin grown in Iran.

\section{MATERIALS AND METHODS}

\section{Study area}

The study was carried out in the experimental farm of Naqadeh Sugar Factory, West Azerbaijan province of Iran. The altitude is $1000 \mathrm{~m}$ at the foot and $2100 \mathrm{~m}$ at the summit of the mountain. The annual average temperature is $11.3-13.71^{\circ} \mathrm{C}$, the summer average is $22.76^{\circ} \mathrm{C}$, and the winter average is $2.45^{\circ} \mathrm{C}$. The coldest months are December-January $\left(-3-0^{\circ} \mathrm{C}\right)$ and the warmest are July-August $\left(24.21^{\circ} \mathrm{C}\right)$. Average precipitation is $326.43 \mathrm{~mm}$. The experimental plot area is $4 \times 4 \mathrm{~m}^{2}$ composed of eight sugar beet sowing ridges with interrow spacing of $50 \mathrm{~cm}$ and inter-plant spacing of $20 \mathrm{~cm}$. After preparation, the plots were manually planted by wet planting on rows on April, 2007. The seeds were of cv. Shirin with $98 \%$ viability and $99 \%$ purity. The plots were thinned and weeded twice - first at 4-6-leaf stage and then at 6-8-leaf stage. All cultivation operations in different fields (weeds control, crust breaking, irrigation, etc.) were carried out to control pests and diseases. The experimental treatments included six levels of granola humic acid (control, 200, 300, 400, 500 , and $600 \mathrm{~kg} \mathrm{ha}^{-1}$ ). Humic acid treatments as foliar application were used before sowing. At harvest time, all plants were harvested after eliminating $0.5 \mathrm{~m}$ from both ends of the plots and two marginal rows.

\section{Soil properties}

Soil physiochemical properties were measured on soil samples taken from the depth of 0-30 cm. Five soil samples were collected randomly from various sites of the cultivation area. Sampling in each site was done before application of humic acid foliar application, using stainless-steel auger. The soil samples were mixed together to form a combined sample, and collected in polyethylene bags and pre-treated by being air-dried at room temperature $\left(25 \pm 1^{\circ} \mathrm{C}\right)$, ground and sieved through 2- $\mathrm{mm}$ for physiochemical analysis.

Soil analysis was performed based on standard methods (Rowell, 1994). Soil pH was measured using 1:5 soil to water ratio suspension with a glass electrode $\mathrm{pH}$ meter (model inolab $\mathrm{pH}$ 7110). Soil electrical conductivity (EC) was measured using a glass electrode (model 712 conductometer) after mixing the soil with water $(1: 5, w / v)$. Organic carbon was determined according to Walky-Black method, which is based on the oxidation of organic matter with $\mathrm{K}_{2} \mathrm{Cr}_{2} \mathrm{O}_{7}$ and $\mathrm{H}_{2} \mathrm{SO}_{4}$ and titration with $\mathrm{FeSO}_{4}$. Olsen-P is the official factor for assessing available $\mathrm{P}$ in soil ( $\mathrm{Lu}, 1999)$. Briefly, $1 \mathrm{~g}$ of aired-dried soil sample and $20 \mathrm{ml}$ of $\mathrm{NaHCO}_{3}(0.5$ mol l-1, $\mathrm{pH}$ 8.5) were placed into a $50 \mathrm{ml}$ extraction bottle; and the bottle was shaken mechanically for 30 min. at room temperature. The suspension was filtered through a Whatman No. 42 free filter paper. The $\mathrm{P}$ concentration in the filtrate was measured by the colorimetric method using ascorbic acid at $820 \mathrm{~nm}$ by spectrophotometer (Model Varian Cary 100). Total nitrogen (TN) was measured according to Kjeldahl digestion method (Baethgen and Alley, 1989). Available potassium $(\mathrm{K})$ concentration was determined using $1 \mathrm{M}$ Ammonium Acetate (Rowell, 1994). Particle-size distribution was determined by the hydrometer method (Gupta and Larson, 1979). Available concentration of micronutrients $(\mathrm{Fe}, \mathrm{Zn}, \mathrm{Mn}$, and $\mathrm{B})$ were measured according to Sposito (2008) using Atomic Adsorption Spectroscopy (AAS, Model Varian Spectra, 220). Soil calcium carbonate content was determined after digestion of $1 \mathrm{~g}$ soil with $\mathrm{HCl} 1 \mathrm{~N}$ according to Rowell (1994).

\section{Qualitative parameters}

Sugar percent and impurities of roots (amino N, K and $\mathrm{Na}$ contents) were measured by betalyser and flame photometer (Kunz 2004). Molasses percent was calculated as follows (Dutton and Bowler, 1984):

$$
\operatorname{MS}(\%)=0.343(\mathrm{~K}+\mathrm{Na})+0.094(\alpha-\mathrm{a} \min \mathrm{o}-\mathrm{N})-0.29
$$

Eq. (1)

Where, MS represents molasses, and $\mathrm{K}, \mathrm{Na}$, and amino $\mathrm{N}$ are expressed in meq $100 \mathrm{~g}^{-1}$ sugar beet root.

White sugar percent or recoverable sugar percent was estimated as the difference in sugar percent and molasses percent as follows (Shoae et al. 2014):

$$
\mathrm{WSC}(\%)=\mathrm{SC}(\%)-\mathrm{MS}(\%)
$$

Where, WSC represent recoverable sugar content, SC represents sugar percent, and MS represents molasses percent.

Sugar percent, includes recoverable sugar percent plus sugar percent of molasses. The sucrose content was measured by polarimetry method (Pospíšilová et al., 2018). The method is based on the deviation percent of polarized light. To measure quantitative parameters of the root, root pulp and lead acetate were mixed with the ratio of $26 \mathrm{~g}$ pulp and $177.7 \mathrm{~cm}^{3}$ lead acetate by automatic mixers, then, it was infiltrated by filter paper No. 42 and the extract was taken. Sugar percent was determined by polarimetry method (Kunz 2004). 
Alkalinity of the studied samples was calculated as below (Abdollahian Noghabi, 2001):

$$
\text { Alkalinity }=\frac{\mathrm{Na}+\mathrm{K}}{\mathrm{N}}
$$

Whereas; $\mathrm{K}$ and $\mathrm{Na}$ content of root pulp extract was measured in terms of meq per $100 \mathrm{~g}$ root pulp by flame photometer which compares the emission spectrum of the sample with that of lithium. Amino-N percent was estimated by betalyser. It expresses amino-N percent in terms of meq per $100 \mathrm{~g}$ root pulp (Kunz 2004).

\section{STATISTICAL Analysis}

The analysis of variance (ANOVA) was performed using (SPSS) statistical software program to compare the effects of humic acid treatments. The means and standard deviations were reported.

\section{RERSULTS AND DISCUSSION}

\section{Soil properties}

Selected chemical and physical properties of the five studied soils are shown in Table 1. According to the obtained $\mathrm{pH}$, soil classified as neutral, (where it average was 7.12) but it is not alkaline soil due to the low EC $\left(0.735 \mathrm{dS} \mathrm{m}^{-1}\right)$. As well as, relatively low organic matter $(0.81 \%)$ and silty clay texture of studied soil samples relevant the appropriate conditions was performed for growing sugar beet (Beta vulgaris L.). Based on soil nutrients analysis, no fertilization was necessary ( $\mathrm{P}$ and $\mathrm{K}$ concentrations more than $15 \mathrm{mg} \mathrm{kg}^{-1}$ and $60 \mathrm{mg} \mathrm{kg}^{-1}$, respectively). The use of organic manures and chemical fertilizers in Iranian agricultural farms is more than the needs of plants and soil according to Water Research Institute Recommendations, which leads to the accumulation of organic and inorganic compounds in soil and their decomposition over time (Dezfuli et al., 2019).

Table 1. Soil characteristics

\begin{tabular}{cc}
\hline Physiochemical properties & \\
\hline Available P (kg/ha) & 9.95 \\
Available K (kg/ha) & 386 \\
Organic matter (\%) & 0.81 \\
Total N (\%) & 0.058 \\
EC (dS/m) & 0.735 \\
Clay (\%) & 42 \\
Silt (\%) & 41 \\
Sand (\%) & 17 \\
Soil texture & Silty clay \\
pH & 7.19 \\
Calcium carbonate (\%) & 15.02 \\
Available Fe (mg kg-1) & 58.04 \\
Available Zn $\left(\mathrm{mg} \mathrm{kg}^{-1}\right)$ & 1.3 \\
Available B (mg kg-1) & 0.36 \\
Available Mn $\left(\mathrm{mg} \mathrm{kg}^{-1}\right)$ & 20.32 \\
\hline
\end{tabular}

Table 2. Humic acid characteristics

\begin{tabular}{cccccc}
\hline $\mathrm{Fe}$ & $\mathrm{Ca}$ & $\mathrm{P}$ & $\mathrm{K}$ & $\mathrm{N}$ & $\mathrm{HA}+\mathrm{FA}$ \\
\hline & & \multicolumn{2}{c}{$(\%)$} & \multicolumn{2}{c}{ Eq. (3) } \\
\hline 4 & 3 & 2 & 8 & 10 & 72 \\
\hline
\end{tabular}

Among all micro nutrient, boron (B) is a critical element for sugar beet. Presence of boron is involved in several physiological and biochemical processes during plant growth. In general, sugar beet in special, boron plays a major role in sugar transport as well as in formation and maintenance of cell wall and cell membrane integrity and consequently, high root yield, and sugar content (Wang et al., 2019). In general, boron improved root weight/plant, top, root and sugar yields/ha and root quality percentage sugar, and extractable white sugar. In other wise, application of boron reduced $\mathrm{N}, \mathrm{Na}$, $\mathrm{K}$ contents, and amino- $\mathrm{N}$ and loss sugar percentage (Hoffmann, 2019). The greatest need for boron is in the stage of intense leave growth, from closing the ranks even reaching the maximum leaf surface (Wilczewski et al., 2018).

\section{Quantitative parameters}

\section{Sodium, potassium, and amino-nitrogen}

Three major impurity components, potassium, sodium and amino-nitrogen could influence sugar yield. Increased amounts of these compounds reduce sugar extractability during processing due to higher sugar loses in molasses (Rahimi et al., 2019). High levels of nitrogen in sugar beet farming cause more accumulation of amino acids and vitamins in the root, making it more difficult to obtain sugar (Noshad et al., 2015). The decrease in sugar content caused by the increase in nitrogen absorption in the soil is due to the growth of shoots to the root, which in turn results in more photosynthetic materials being used in the shoots. However, a decrease in dry matter concentration or an increase in the water content of fresh roots may be attributed to other factors such as sodium concentration or $\mathrm{K} / \mathrm{Na}$ ratio in the root (Nemeata et al., 2018). Sodium concentration in plant tissues is affected by the amount of nitrogen consumed, harvest time and type of plant organs; and unlike potassium, its concentration in all plant organs decreases over time during the growth period. With the application of nitrogen, the concentration of sodium in all plant organs increases, but the concentration of potassium in the root only increases with the application of nitrogen. Studies by researchers have shown a positive correlation between sugar content and potassium to sodium ratio in root sugar beet (Hassani et al., 2018). For these reasons, the amount of these compounds are important in sugar industry. The mean value of these substances for all humic acid treatments are reported in Fig. 1. 
Accordingly, humic acid application decreased the amount of these compounds of sugar beet. Especially, application of humic acid at $300 \mathrm{~kg} \mathrm{ha}^{-1}$ decreased amounts of these impurities, whereas the highest amount of these impurities was observed in control. Meanwhile there was a significant decrease in impurities (ton ha-1) of sugar beet plants by increasing humic acid rates from zero up to $300 \mathrm{~kg} / \mathrm{ha}$. These results are in harmony with those obtained by Olk et al (2018) and El-Sayed et al (2019), who revealed that increasing humic acid made up a decrease in sodium, potassium, and amino nitrogen contents of sugar beet up to $300 \mathrm{~kg} \mathrm{ha}^{-1}$. Based on the obtained results, increasing humic acid level above $300 \mathrm{~kg} \mathrm{ha}^{-1}$, caused to increase of sodium and potassium concentrations in sugar beet. However, no significant decrease was observed in amino nitrogen content by increasing of humic acid level from 300 to $600 \mathrm{~kg} / \mathrm{ha}$.

\section{Alkalinity}

Alkalinity is a process factor which influence sugar quality with regards to $\mathrm{N}, \mathrm{K}$, and $\mathrm{Na}$. The effect of humic acid on the sugar beet alkalinity was shown in Figure 2. Generally, alkalinity of sugar beet increased with humic acid application up to $400 \mathrm{~kg} \mathrm{ha}^{-1}$. The major increase observed in sample treated with $400 \mathrm{~kg}$ $\mathrm{ha}^{-1}$ humic acid (Fig. 2). The increase alkalinity increase for sugar beet could be related non-sugar compounds in sugar beet roots such as amino-nitrogen, $\mathrm{Na}$ and $\mathrm{K}$ (Feizi, et al. 2017). The results are in harmony with those obtained by Dawood et al (2019). However, the higher application of humic acid (500 and $\left.600 \mathrm{~kg} \mathrm{ha}^{-1}\right)$ was decreased the alkalinity significantly $(\mathrm{P} \leq 0.05)$.

\section{Sugar content}

The effect of humic acid application on some quantitative parameters of sugar beet was shown in Fig. 4. According to these results, all humic acid applications effected positively sugar content and recoverable sugar content compared to control sample. However, there was a decrease in sugar content in molasses with increasing of humic acid dosage. As seen in Fig. 4, the sugar content found higher value $(18.1 \%)$ in sample at $400 \mathrm{~kg} \mathrm{ha}^{-1}$ humic acid and sugar content of other samples had higher than control sample. The highest white or recoverable sugar content $(15.64 \%)$ was obtained with the application of $500 \mathrm{~kg} \mathrm{ha}^{-1}$ humic acid. Sugar content in molasses was determined as a quality parameter in sugar production. The lower value $(2.14 \%)$ for this parameter were recorded in samples treated with $300 \mathrm{~kg} \mathrm{ha}^{-1}$ humic acid, while the highest (3.90\%) sugar content in molasses was recorded in control sample.

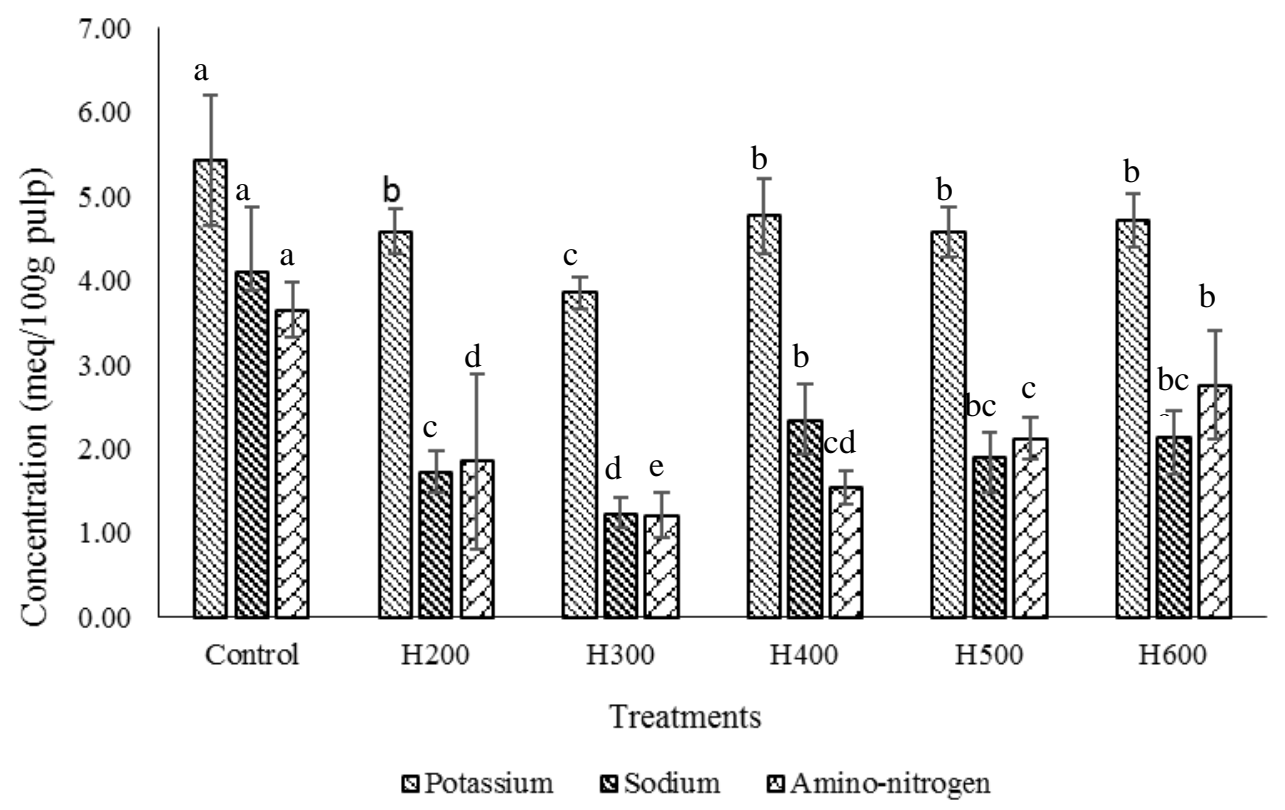

Fig. 1. The concentration of sugar beet as a result of treatments 


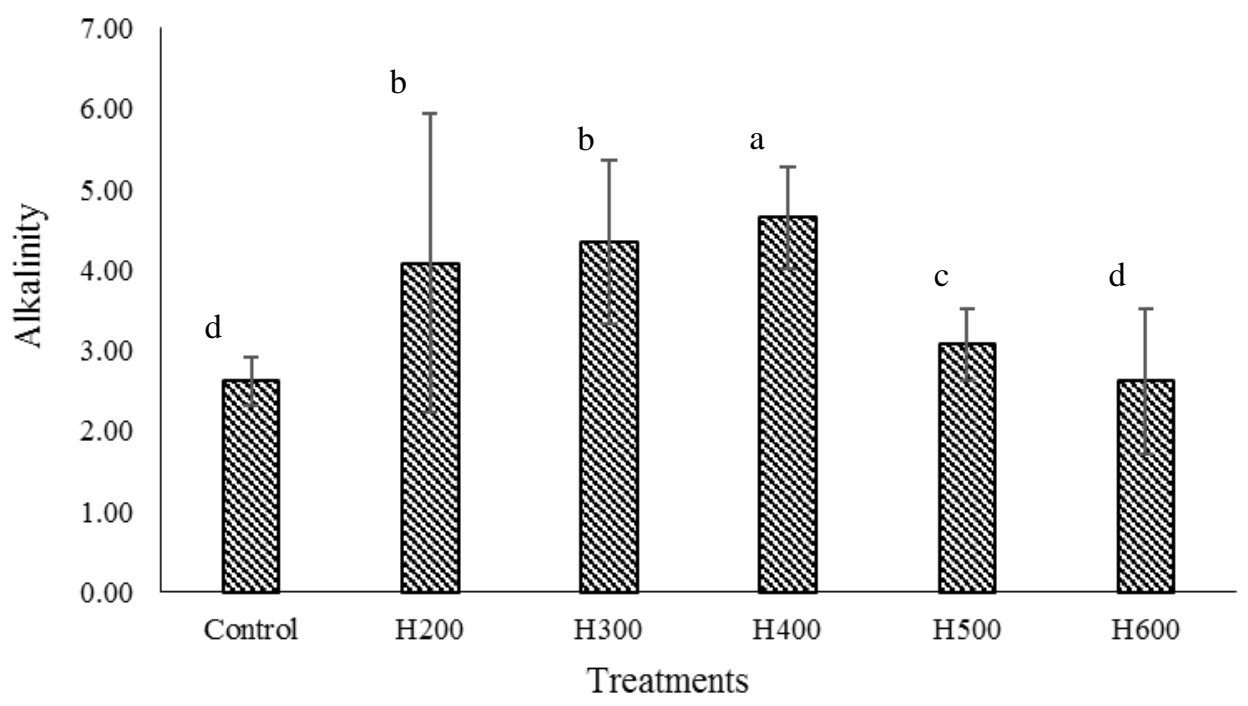

Fig. 2. Alkalinity of sugar beet as a results of treatments

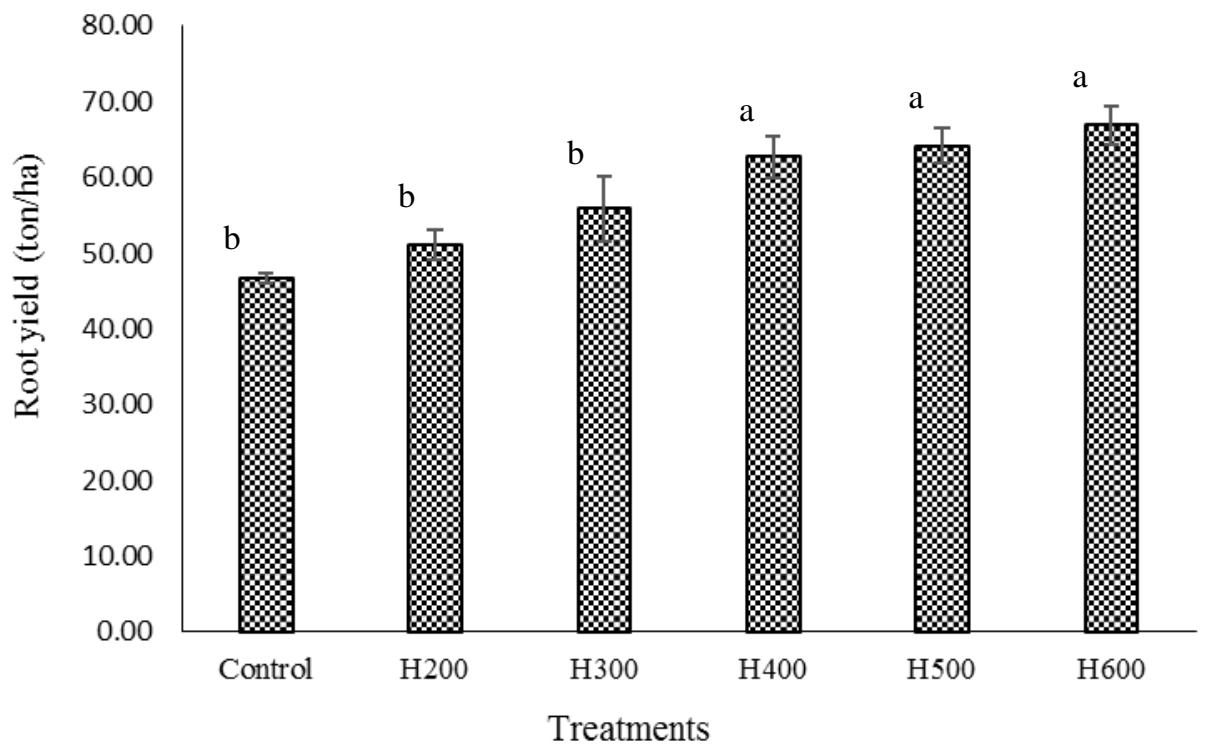

Fig. 3. Root yield of sugar beet as a result of treatments

Since recoverable sugar content is subordinate to two components of root yield and sugar content, therefore increasing the amount of humic acid consumed can increase recoverable sugar yield by increasing root yield (Rehab et al., 2019). Previous research has shown that the use of humic acid reduces molasses sugar by reducing root impurities (Sudiono et al., 2017).

\section{CONCLUSION}

The results obtained in this study indicated that humic acid application enhances quality parameters of sugar and also sugar beet. Non-sugar (K, Na and aminonitrogen) content of sugar beet pulp decrease recoverable sugar content and increase sugar in molasses. All samples treated with humic acid showed lower content for these non-sugar compounds compared to control samples. Alkalinity of sugar beet was an important factor in sugar production. The alkalinity of samples with treated humic acid were higher than 
control sample. Recoverable sugar content found rich in sample with treatment at $500 \mathrm{~kg} \mathrm{ha}^{-1}$ humic acid. Use of humic acid for sustainable agricultural purposes can compensate for food shortages, maintain soil fertility and sustainable production.

\section{ACKNOWLEDGMENT}

The authors are thankful to the Office of Vice Chancellor for Research and Technology, Urmia University.

Declarations of interest: The authors declare that they have no conflict of interest.

\section{REFERENCES}

Albayrak, S. and N. Camas.2005. Effects of different levels and application times of humic acid on root and leaf yield and yield components of forage turnip (Brassica rapa L.). J Agron Crop Sci: 101-119.

Akhtar, T, S. M. Ismail and F. S. Al-Nakhlawy.2017. Optimization of Humic acid application rate by evaluating the response of mung been (Vigna radiata) yield, growth components and soil properties in western region of Saudi Arabia. Int. J. Biosci: 240-248.

Aly, E. F. A, S. R. Khalil and M. E. Abdel Fattah. 2017. Effect of Boron, Potassium and Calcium on Growth, Yield and Quality of Two Sugar Beet Varieties under Sandy Soil Conditions. Int. J. Plant. Prod: 699-704.

Asadi, M. 2007. Beet Sugar Handbook. John Wiley \& Sons, Inc., Hoboken.

Abdollahian-Noghabi, M. 2001.Study of using the formulas to estimate molasses sugar under Iran climate conditions. Proceedings of the 23th Seminar of Iran Sugar Industries; Mashad, Iran. P:192-199. (in Persian)

Barone, V., A. Baglieri, P. Stevanato, C. Broccanello, G. Bertoldo, M. Bertaggia and F. Fornasier. 2018. Root morphological and molecular responses induced by microalgae extracts in sugar beet (Beta vulgaris L.). J. Appl. Phycol: 1061-1071.

Baethgen, W. E. and M. M. Alley. 1989. A manual colorimetric procedure for measuring ammonium nitrogen in soil and plant Kjeldahl digests.

Commun Soil Sci Plant: 961-969.

Campbell, L. G. 2002. Sugar beet quality improvement. J. Crop Production, 5(1-2):395-413.

Curcic, Z., M. Ciric, N. Nagl and K. Taski-Ajdukovic. 2018. Effect of sugar beet genotype, planting and harvesting dates and their interaction on sugar yield. Front. Plant Sci: 1041-1049.

Dutton, J.V. and G. Bowler. 1984.Money is still being wasted on nitrogen fertilizer. Brit. Sugar Beet Rev.Dutton J, Huijbregts T. Root quality and processing A.P. Draycott (Ed.), Sugar Beet, Blackwell Publishing, Oxford.2006., pp:409-442.

Dawood, M. G., Y. R. Abdel-Baky, M. E. S. El-Awadi and G. S. Bakhoum. 2019. Enhancement quality and quantity of faba bean plants grown under sandy soil conditions by nicotinamide and/or humic acid application. Front. Plant Sci: 28-36.
Dezfuli, M., A. Shokuhfar, S. Lak and M. Alavifazel. 2019.The Effect of Potassium and Zinc Foliar application time on Grain Yield, Qualitative Traits and water Use Efficiency (WUE) of Corn (Zea Maize L.) under Deficit Irrigation Conditions. J Agron Crop Sci: 79-88.

El-Hassanin, A. S., M. R. Samak, N. Moustafa, A. M. Shafika, Khalifa, N.Ibrahim and M. Inas. 2016. Effect of foliar application with humic acid substances under nitrogen fertilization levels on quality and yields of sugar beet plant. Int J. Current Microb and Appl Sci: 668-680.

Ekin, Z. 2019. Integrated Use of Humic Acid and Plant Growth Promoting Rhizobacteria to Ensure Higher Potato Productivity in Sustainable Agriculture. Sustainability: 3417-3425.

El-Sayed, H. A., M. A. A. El-Sherbini and M. T. M. Al-Ashry. 2019. Improving Sugar Pea Growth and Quality by using some Natural Substances. J. Plant Prod: 299-306.

El-Sheshtawy, A. A., M. A.Hager and S. S. Shawer.2018. Effect of bio-fertilizer, Phosphorus source and humic substances on yield, yield components and nutrients uptake by barley plant. Int J. Current Microb and Appl Sci: $256-262$.

Feizi, M., J.Fallahzade and P. Noorshargh .2017.Sugar beet yield response to different levels of saline irrigation water and leaching in an arid region. J. Plant. Nut: 1-10.

Fuentes, M., E. Bacaicoa, M. Rivero, Á. M. Zamarreño and M. García-MinaJ. 2018.Complementary evaluation of iron deficiency root responses to assess the effectiveness of different iron foliar applications for chlorosis remediation. Front. Plant Sci: 351-359.

Gholami, H., F. R. Fard, M. J. Saharkhiz and A. Ghani .2018.. Yield and physicochemical properties of inulin obtained from Iranian chicory roots under vermicompost and humic acid treatments. Indust. crops and prod: 610-616.

Gupta, S. and W. E. Larson. 1979. Estimating soil water retention characteristics from particle size distribution, organic matter percent, and bulk density. Water Resour Res: 1633-1635.

Hoffmann, C. M. 2010. Root quality of sugarbeet. Sugar Tech, 12(3-4): 276-287.

Hassani, M., B. Heidari, A. Dadkhodaie and P. Stevanato. 2018. Genotype by environment interaction components underlying variations in root, sugar and white sugar yield in sugar beet (Beta vulgaris L.). Euphytica: 79-84.

Hoffmann, C. M. 2019. Importance of canopy closure and dry matter partitioning for yield formation of sugar beet varieties. Front. Plant Sci: 75-84.

Kaya, C., N. Akram, M. Ashraf and O. Sonmez. 2018. Exogenous application of humic acid mitigates salinity stress in maize (Zea mays L.) plants by improving some key physico-biochemical attributes. Cereal Res Commun: 67-78.

Kunz, M. 2004. Sugar analysis. Beet. The international commission for uniform methods of sugar analysis (ICUMSA), General Subject:110-117. 
Kheir, A. and M. Kamara. 2019. Effects of Sugar Beet Factory Lime, Vinasse, and Compost Mixed with Vinasse Application on Sandy Soil Properties and Canola Productivity. J.Soil Sci Agri Engin: 69-77.

Nemeata, A. H., A. Sasy and S. A. Helmy. 2018.Effect of Potassium Humate and Nitrogen Fertilization on Yield and Quality of Sugar Beet in Sandy Soil. J. Plant Prod: 333338.

Noshad, H., R. Mohammadian, S. Khayamim and F. Hamdi. 2015.Effect of amino acid containing organic fertilizers on nitrogen use efficiency and qualitative and quantitative properties of sugar beet. J. Sugar Beet: 95-102.

Orsi, M. 2014. Molecular dynamics simulation of humic substances. Chem. Bio Tech in Agri: 10-18.

Osman, A. S. And M. M. Rady.2012. Ameliorative effects of sulphur and humic acid on the growth, anti-oxidant levels, and yields of pea (Pisum sativum L.) plants grown in reclaimed saline soil. J. Hortic. Sci: 626-632.

Olk, D. C., D. Dinnes, J. R. Scoresby, C. R. Callaway and J. W. Darlington. 2018. Humic products in agriculture: potential benefits and research challenges - a review. J Soil Sediment: 2881-2891.

Özbay, S. and M. Yildrim. 2015. The response of sugar beet to different irrigation levels and foliar application of micronutrients under drip irrigation system. Mediterr. Agric. Sci: 16-23.

Peña-Méndez, E. M., J. Havel and J. Patočka.2005. Humic substances-compounds of still unknown structure: applications in agriculture, industry, environment, and biomedicine. J. Appl. Biosci: 13-24.

Pospíšilová, L. U., J. Novotná, V. Vlček and B. Badalíková. 2018. Soil inputs and dynamic of humi substances in chernozems. International Multidisciplinary Scientific Geo Conference: SGEM: Front. Plant Sci: 495-501.

Rowell, D.L. 1994. Soil Science: Method and Application. Longman Group, Harlow. p.345.
Rahimi, A., S. S. Moghaddam, S. A. Noorhosseini and M. Hajyzadeh.2019. Effects of Foliar Application of Micronutrients on Agronomic Traits of Beet Cv. Sonja under Dsa (Hot Summer Continental) Climatic conditions of Naqadeh Iran. Turk. tarım gida bilim teknol: 828-832.

Rehab, I., S. S. El Maghraby, E. E. Kandil and N. Y. Ibrahim. 2019. Productivity and Quality of Sugar Beet in Relation to Humic Acid and Boron Fertilization under Nubaria Conditions. Euphytica: 115-126.

Sudiono, S., M. Yuniarti, D. Siswanta, E. S. Kunarti, T. Triyono and S. J. Santosa. 2017. The Role of Carboxyl and Hydroxyl Groups of Humic Acid in Removing AuCl 4-from Aqueous Solution. Indones. J. Chem: 95-104.

Sposito, G. 2008. The chemistry of soils. Oxford university press.

Shoae, M.S., D. Habibi, D.F. Taleghani, F. Paknejad and A. Kashani . 2014. Response of Autumn Sugar Beet to Foliar Application of Paclobutrazol in Karaj Region. Indones. J. Chem: 12-17.

Shahabivand, S., A. Padash, A. Aghaee, Y. Nasiri, R. P. Fathi. 2018. Plant biostimulants (Funneliformis mosseae and humic substances) rather than chemical fertilizer improved biochemical responses in peppermint. Plant Physiol: 23332344.

Tan, K. H. and V. Nopamornbodi. 1979. Effect of different levels of humic acids on nutrient content and growth of corn (Zea mays L.). Plant soil: 283-287.

Thalooth, A. T., M. M. Tawfik, E. A. Badre and M. H. Mohamed. 2019. Yield and quality response of some sugar beet (Beta vulgaris L.) varieties to humic acid and yeast application in newly reclaimed soil. Plant Physiol: 56-65.

Wilczewski, E., M. Szczepanek and A. Wenda-Piesik. 2018. Response of sugar beet to humic substances and foliar fertilization with potassium. Plant Physiol: 153-165.

Wang, M., Y. Xu, W. Wang, Z. Wu, W. Xing, H. Zhang. 2019. Quantitative Trait Locus (QTL) Mapping of Sugar Yield-Related Traits in Sugar Beet (Beta vulgaris L.). Sugar Technol: 135-144. 